\title{
Banana as Adjunct in Beer Production: Applicability and Performance of Fermentative Parameters
}

\author{
Giovani B. M. Carvalho • Daniel P. Silva • \\ Camila V. Bento • António A. Vicente • José A. Teixeira • \\ Maria das Graças A. Felipe • João B. Almeida e Silva
}

Received: 22 May 2008 / Accepted: 26 November 2008 /

Published online: 17 December 2008

(C) Humana Press 2008

\begin{abstract}
Traditionally, the raw materials for beer production are barley, hops, water, and yeast, but most brewers use also different adjuncts. During the alcoholic fermentation, the contribution of aroma compounds from other ingredients to the final beer flavor depends on the wort composition, on the yeast strain, and mainly on the process conditions. In this context, banana can also be a raw material favorable to alcoholic fermentation being rich in carbohydrates and minerals and providing low acidity. In this work, the objective was to evaluate the performance of wort adjusted with banana juice in different concentrations. For this, static fermentations were conducted at $15{ }^{\circ} \mathrm{C}$ at pilot scale (140 L of medium). The addition of banana that changed the concentration of all-malt wort from $10{ }^{\circ} \mathrm{P}$ to 12 and $15^{\circ} \mathrm{P}$ were evaluated $\left({ }^{\circ} \mathrm{P}\right.$ is the weight of the extract or the sugar equivalent in $100 \mathrm{~g}$ solution, at $20{ }^{\circ} \mathrm{C}$ ). The results showed an increase in ethanol production, with approximately $0.4 \mathrm{~g} / \mathrm{g}$ ethanol yield and $0.6 \mathrm{~g} / \mathrm{L} \mathrm{h}$ volumetric productivity after $84 \mathrm{~h}$ of processing when concentrated wort was used. Thus, it was concluded that banana can be used as an adjunct in brewing methods, helping in the development of new products as well as in obtaining concentrated worts.
\end{abstract}

Keywords Beer $\cdot$ Raw materials $\cdot$ Adjunct $\cdot$ Banana $\cdot$ Brewing $\cdot$ Fermentation

\section{Introduction}

Traditionally, the raw materials for beer production are malted grains of barley, hops, water, and yeast, but most brewers add different adjuncts. Conventional beer fermentation

G. B. M. Carvalho · C. V. Bento • M. G. A. Felipe • J. B. Almeida e Silva

Biotechnology Department, Engineering School of Lorena, University of São Paulo, Campus I,

P.O. Box 116, 12602-810 Lorena, SP, Brazil

D. P. Silva $(\bowtie) \cdot$ A. A. Vicente $\cdot$ J. A. Teixeira

Centre of Biological Engineering, IBB - Institute for Biotechnology and Bioengineering,

University of Minho, Campus de Gualtar, 4710-057 Braga, Portugal

e-mail: silvadp@deb.uminho.pt

e-mail: silvadp@hotmail.com 
technology is based on batch fermentation of wort, with no mechanical stirring and with specific temperature profiles during fermentation to obtain the desired characteristics, such as ethanol concentration, taste, and aroma on the final product. According to Linko et al. [1], beer production consists of four stages: (a) malting (based on germination and treatment of barley); (b) mashing or wort production (extraction and hydrolysis of the components of malt and possibly other cereals, followed by separation of non-soluble components and boiling with hops); (c) fermentation stages (in most cases divided into main fermentation and lagering or maturation); and (d) down-stream processing (filtration, stabilization, bottling, and other treatments of the final product; Fig. 1).

Presently, there are many variations of this brewing process due to improvements in technical, biochemical, microbiological, and genetic inventions implemented by the modern brewing industry [1-5]. Previously, we evaluated a new technology of high gravity brewing for selectively producing beers from more concentrated wort (using high maltose syrup) with the goal of producing good quality beer with less time and expense [6-9]. In an industrial context, traditional brewing uses worts of $10-12{ }^{\circ} \mathrm{P}$ to produce beers with $4-5 \%$ $v / v$ ethanol content, while the high gravity technique involves preparation and fermentation of media higher than $12^{\circ} \mathrm{P}$ (degrees Plato, which is the weight of the extract or the sugar equivalent in $100 \mathrm{~g}$ of the solution at $20^{\circ} \mathrm{C}$ ). By increasing wort concentration, after

Fig. 1 Simplified scheme for brewing, adapted from Linko et al. [1]

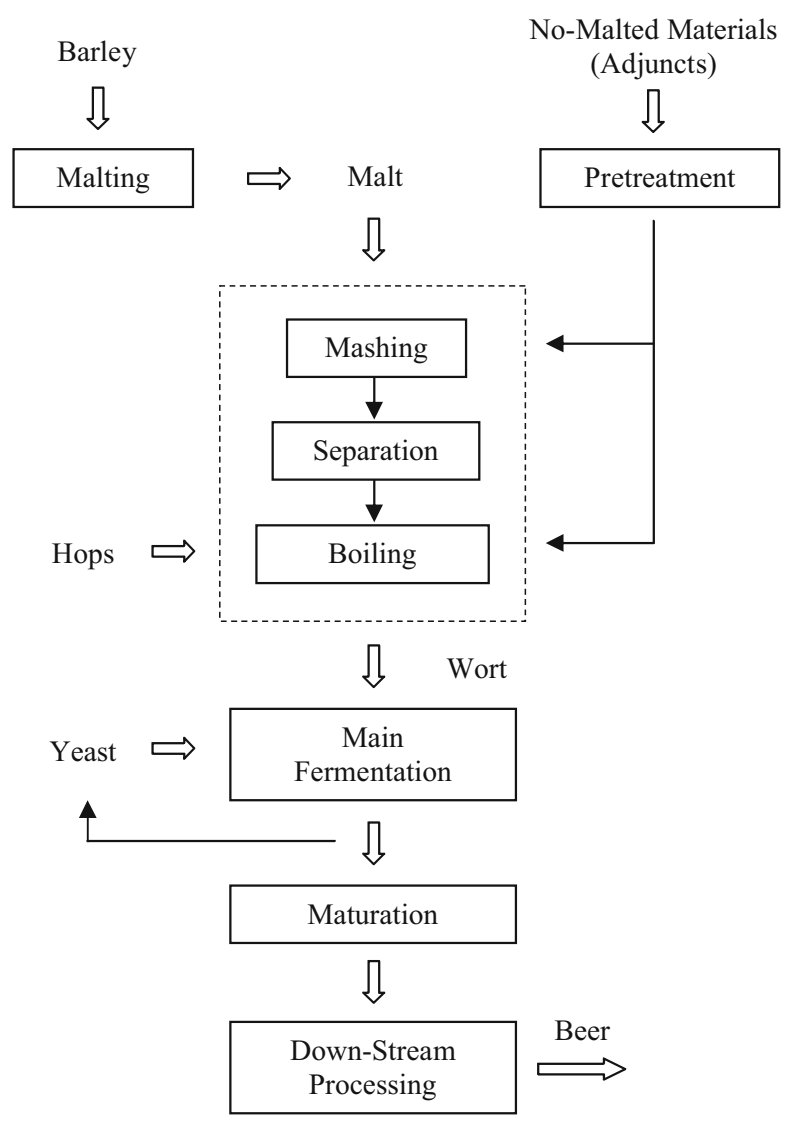


preparation, the beer is adjusted to the desired ethanol concentration with oxygen-free water producing higher ethanol yields more efficiently [10-13].

Recently, new techniques and processes have been developed using several adjuncts for production of different beers such as alcohol-free, low-alcohol, or aromatic beers [14-16].

Banana fruits are produced in large quantities in tropical and subtropical areas. Besides being one of the most significant foodstuffs in the world, banana is one of the oldest fruits known to mankind as an important energy-producing food, while being also a good source of mineral salts and vitamins [17]. Banana is a general term embracing a number of species or hybrids in the genus Musa of the family Musaceae, which are native to Southeast Asia [18]. Today, Cavendish subgroup banana cultivars (M. cavendishii) are the mainstays of the export trades [18]. However, as is the case for most tropical products, due to the special climatic conditions needed to grow bananas, they are mainly produced in developing countries. According to the Food and Agriculture Organization of the United Nations [19], India produced the most with $11.7 \times 10^{6}$ tonnes in 2006 , which corresponded to $16.5 \%$ of the worldwide production, and Brazil was the second with $7.1 \times 10^{6}$ tonnes (approximately $10 \%$ of the worldwide production).

Banana can also be a raw material for alcoholic fermentation, being rich in carbohydrates and minerals and providing low acidity. Because of the high yields and low production costs of bananas, many countries such as Brazil have been utilizing them widely. In fact, recent research has shown that banana has potential, both from its functional properties and as an economic activity, for application in processed foods and has become a commercially viable product in terms of its use as an industrial raw material $[17,20]$.

According to Viviani and Leal [20], inadequate handling of bananas during the postharvest is the main reason for the loss of value of the product and for the loss of export opportunities. For these reasons, research aimed at applying banana juice as an adjunct in brewing processes has scientific interest and great potential in many tropical bananaproducing countries.

The goals of this research are to describe and evaluate the effects of the use of banana juice adjunct and its application in concentrated wort on the performance of fermentation parameters in a brewing process. Special attention was paid to fermentation performance in terms of volumetric productivity, ethanol yield, and sugar consumption. The study evaluated the addition of banana juice to change the concentration of all-malt wort from $10{ }^{\circ} \mathrm{P}$ to 12 and $15^{\circ} \mathrm{P}$. There is little or no information on the application or evaluation of banana adjuncts in high gravity fermentation technology to the brewing of beer in the literature.

\section{Materials and Methods}

Yeast Strain and Inoculum Preparation

The yeast strain used in this work was a commercial lager brewing strain (Saccharomyces cerevisiae) maintained on malt-agar slants at $4{ }^{\circ} \mathrm{C}$. The yeast biomass for initial inoculation in the fermentation reactor was cultivated on a rotary shaker $\left(200 \mathrm{~mL} / 30^{\circ} \mathrm{C} / 200 \mathrm{rpm}, 18 \mathrm{~h}\right)$, followed by a 4-L Erlenmeyer flask under static and aerobic conditions $\left(2 \mathrm{~L} / 15^{\circ} \mathrm{C} / 0.1 \mathrm{vvm}\right.$ of aeration, $30 \mathrm{~h}$ ), then in a 40 -L stainless steel vessel under static and aerobic conditions $\left(20 \mathrm{~L} / 15^{\circ} \mathrm{C} / 0.01 \mathrm{vvm}\right.$ of aeration, 54-60 h) until the cell concentration was sufficient to provide a cell concentration of $10-20 \times 10^{6}$ cells $/ \mathrm{mL}$ for the fermentation in the pilot tank $(140 \mathrm{~L})$. All inoculum preparations were carried out using all-malt wort $\left(12.5^{\circ} \mathrm{P}\right)$.

\section{津: Humana Press}




\section{Wort Production and Fermentation Conditions}

Worts were produced according to conventional brewing techniques in the pilot installation used for the experiments (pilot brewery of the Biotechnology Department of the Engineering School of Lorena, University of São Paulo USP/Brazil, as shown in Fig. 2). Banana juice, prepared from fruits of the variety Prata (Musa spp.) and provided by EMATER (Empresa de Assistência Técnica e Extensão Rural do Estado de Minas Gerais, Cristina-MG/Brazil), was used to change the concentration of the all-malt wort from $10^{\circ} \mathrm{P}$ to 12 and $15^{\circ} \mathrm{P}$. The typical carbohydrate profile of the banana used in this research (classified by the peel color as ripening stage 8 - yellow with more brown specks, according Loeseck [21]) was $12.4 \% \mathrm{w} / \mathrm{w}$ sugars as glucose and fructose, $3.2 \% \mathrm{w} / \mathrm{w}$ sugars as sucrose, and $0.5 \% \mathrm{w} / \mathrm{w}$ starch. The banana juice was produced in a solution of $0.29 \mathrm{~g} / \mathrm{L}$ by enzymatic treatment $\left(43.2{ }^{\circ} \mathrm{C}\right.$ during $1.3 \mathrm{~h}$, with agitation of $32 \mathrm{rpm}, \mathrm{pH} 5$, and $8.4 \times 10^{-7} \mathrm{~L}$ of Ultra Pectinex SP-L enzymatic pectinolytic solution by gram of medium) with subsequent thermal treatment $\left(84{ }^{\circ} \mathrm{C}\right.$ during $\left.0.67 \mathrm{~h}\right)$ and mixed to the all-malt wort during the initial stage of wort preparation.

The initial $\mathrm{pH}$ value of the obtained wort was adjusted to 5 (by the addition of lactic acid), and the initial dissolved oxygen concentration was set at approximately $8 \mathrm{mg} / \mathrm{L}$. Static fermentations were performed in a 180 -L cylindrical-conical tank (brewing fermenter) with $140 \mathrm{~L}$ working volume at a constant temperature of $15{ }^{\circ} \mathrm{C}$ and wort concentrations of 12 and $15^{\circ} \mathrm{P}$. A preliminary pilot-scale fermentation trial was conducted in order to gain an understanding of the conventional brewing process as well as to determine the performance of fermentations using all-malt wort under the same process conditions. The fermentation runs were carried out until the apparent attenuation was about $70-75 \%$ (1.0 ${ }^{\circ} \mathrm{P}$ above the final value of fermentable sugars).

\section{Analytical Methodology}

During fermentations, samples were taken in triplicate and the yeast was removed by centrifugation at $4,000 \times \mathrm{g}$ for $20 \mathrm{~min}$. The apparent extract and ethanol concentrations in the supernatant were measured at $20{ }^{\circ} \mathrm{C}$ using an automatic beer analyzer (Beer Analyzer 2, Anton Paar, Graz, Austria). Part of the supernatant was also filtered through a syringe filter

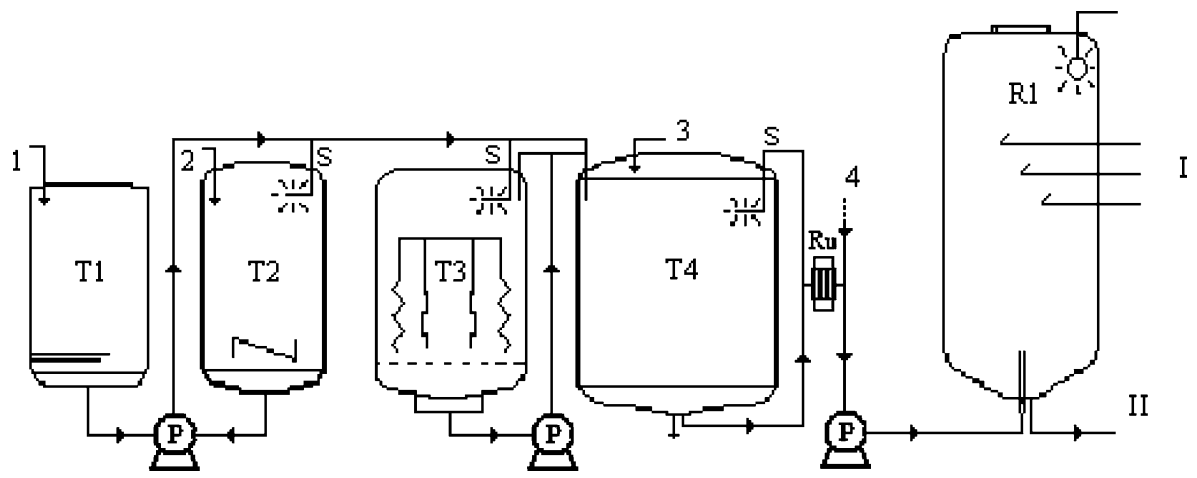

Fig. 2 Pilot system for wort preparation and beer fermentation (pilot brewery of the Biotechnology Department at the Engineering School of Lorena, University of São Paulo USP/Brazil): $T 1$ hot water tank, T2 wort treatment tank, T3 filtration tank, T4 boiling tank, $P$ pumps, $S$ spray balls (in-line cleaning system), $R u$ refrigeration unit, $R I$ fermentation/maturation reactor, $I$ and $I I$ sampling points or final product, 1 water supply, 2 malt supply, 3 hops supply, 4 air/ $\mathrm{O}_{2}$ supply 
Fig. 3 Apparent extract consumption (filled square), ethanol production (filled triangle), and yeast in suspension (empty circle) during all-malt wort brewing process (main fermentation) under the following conditions: initial wort concentration of $12^{\circ} \mathrm{P}$, constant temperature of $15^{\circ} \mathrm{C}$

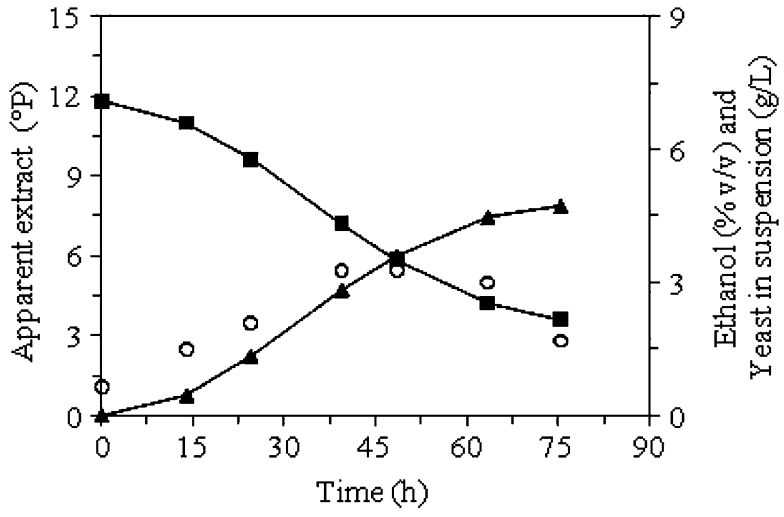

(Sep-Pak C18 cartridge, Waters, Milford, MA, USA), and $20 \mu \mathrm{L}$ was injected into an HPLC system which consisted of an Aminex HPX-87H column $\left(300 \times 7.8 \mathrm{~mm}^{2}\right.$, Bio-Rad Laboratories Ltd, Hercules, CA, USA) at $45{ }^{\circ} \mathrm{C}$ using a Shimadzu chromatograph LC10AD (Shimadzu Co., Tokyo, Japan) with refractive index detector. The mobile phase was $0.005 \mathrm{~mol} / \mathrm{L} \mathrm{H}_{2} \mathrm{SO}_{4}$ at $0.6 \mathrm{~mL} / \mathrm{min}$ flow rate. Sugar concentrations, reported as glucose, fructose, maltose, and maltotriose, were determined from calibration curves obtained with pure compounds.

The yeast cell number was determined using a Neubauer counting chamber, and the viability was determined by methylene blue staining. All analyses were based on the techniques described in ASBC [22]. Each determination was made in triplicate.

The specific substrate consumption rates $\left(\mu_{\mathrm{Si}}\right)$ were defined as:

$$
\mu_{\mathrm{Si}}=(1 / X) \times d \mathrm{Si} / d t
$$

where Si represents the type of carbohydrate evaluated (maltose, glucose, fructose, or maltotriose). The derivatives $\mathrm{dSi} / \mathrm{d} t$ were calculated according to the method proposed by Le Duy and Zajic [23].

The ethanol productivity (ratio between ethanol produced and total fermentation time, $\mathrm{g} / \mathrm{L} \mathrm{h}$ ) and the ethanol yield coefficient (ratio between produced ethanol and consumed extract, $\mathrm{g} / \mathrm{g}$ ) were determined after conversion of the apparent extract $\left({ }^{\circ} \mathrm{P}\right)$ to grams of extract per liter of wort $(\mathrm{g} / \mathrm{L})$.

Fig. 4 Percentage of viable cells (filled triangle) and performance of $S$. cerevisiae in suspension (filled circle) during all-malt wort brewing process (main fermentation) under the following conditions: initial wort concentration of $12^{\circ} \mathrm{P}$, constant temperature of $15{ }^{\circ} \mathrm{C}$

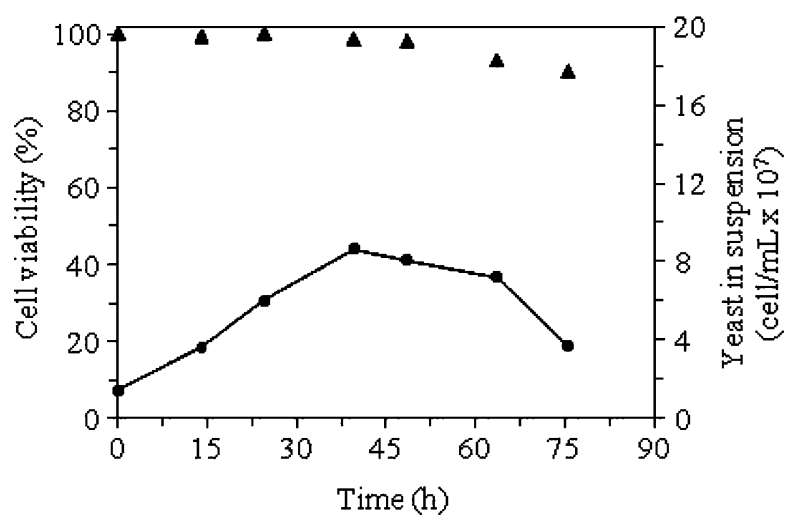


Fig. 5 Performance of $S$. cerevisiae (lager strain) and percentage of viable cells during fermentation processes of wort supplemented with banana juice under the following conditions: $12{ }^{\circ} \mathrm{P} / 15^{\circ} \mathrm{C}$ (cell viabilityempty triangle, and yeast in suspension-empty circle), and $15^{\circ} \mathrm{P} / 15^{\circ} \mathrm{C}$ (cell viabilityfilled triangle and yeast in suspension-filled circle)

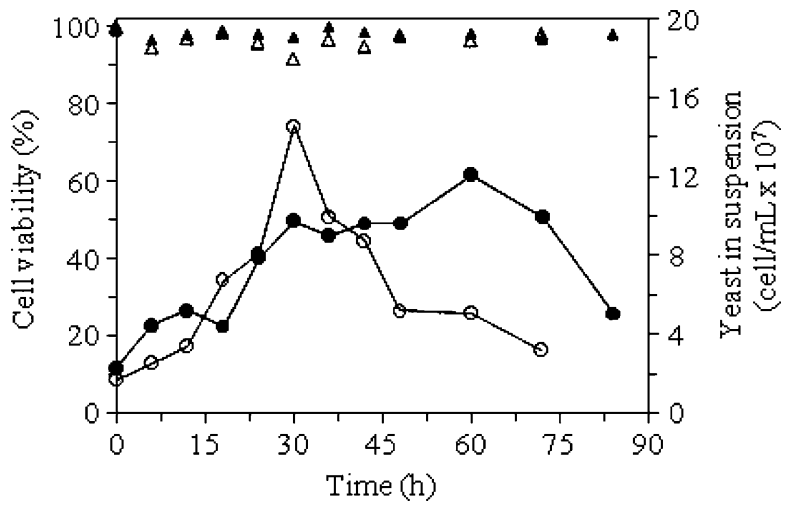

\section{Results and Discussion}

In the preliminary pilot-scale fermentation, using all-malt wort, changes in wort gravity, ethanol production, and cell suspension behavior were evaluated during fermentation at constant temperature of $15{ }^{\circ} \mathrm{C}$, as shown in Fig. 3. During the first $40 \mathrm{~h}$ of fermentation, substrate consumption (measured in terms of apparent extract) was closely related to the increase of yeast biomass in suspension. In this interval ( 0 to $40 \mathrm{~h})$, the apparent extract decreased by approximately $40 \%$, while the suspended cell concentration increased fivefold. Concurrently, ethanol production reached a concentration of $2.9 \%(v / v)$. However, at the conclusion of $75.5 \mathrm{~h}$ (final fermentation time), the concentration of yeast in suspension decreased to twice the initial concentration, while the apparent extract concentration decreased to $3.6^{\circ} \mathrm{P}$ and the ethanol concentration increased to $4.7 \%(\mathrm{v} / \mathrm{v})$.

According to Guido et al. [24], the efficiency of fermentation, the character, and quality of the final product in the brewing process are intimately linked with the amount and health of the yeast being pitched. Evaluating and predicting the cell viability as well as the performance of the brewer's yeast during the fermentative stage is therefore an important requisite. Information was obtained in our research by monitoring the percentage of viable cells and the performance of $S$. cerevisiae in suspension when using all-malt wort during the main fermentation (initial wort concentration of $12{ }^{\circ} \mathrm{P}$, at constant temperature of $15^{\circ} \mathrm{C}$; Fig. 4). The concentration of cells in suspension reached a maximum value of $8.6 \times 10^{7} \mathrm{cell} / \mathrm{mL}$ at

Fig. 6 Extract consumption and ethanol production during fermentation processes of wort supplemented with banana juice under the following conditions: $12{ }^{\circ} \mathrm{P} / 15^{\circ} \mathrm{C}$ (apparent extractempty square, and ethanol concentration-empty triangle), and $15^{\circ} \mathrm{P} / 15^{\circ} \mathrm{C}$ (apparent extract-filled square and ethanol concentration-filled triangle)

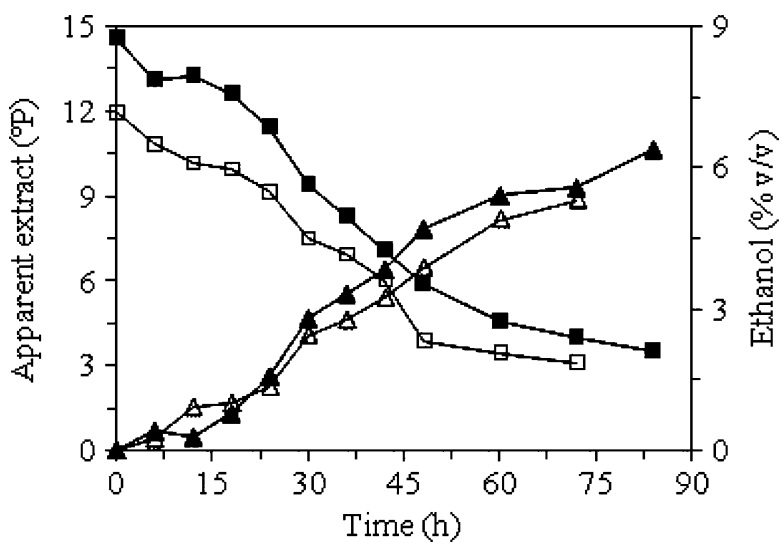


Table 1 Control and fermentative parameters used during the main fermentation process of all-malt wort $\left(12{ }^{\circ} \mathrm{P} / 15^{\circ} \mathrm{C}\right)$ and wort supplemented with banana juice $\left(12\right.$ and $\left.15^{\circ} \mathrm{P} / 15^{\circ} \mathrm{C}\right)$ : total time (time), final ethanol concentration (Eth), ethanol volumetric productivity $(\mathrm{Pr})$, and yield coefficient $\left(Y_{\mathrm{P} / \mathrm{S}}\right)$, at the end of each fermentation run.

\begin{tabular}{|c|c|c|c|c|}
\hline \multirow[t]{2}{*}{ Fermentation medium (type and concentration) } & \multicolumn{4}{|c|}{ Control and fermentative parameters } \\
\hline & Time $(\mathrm{h})$ & Eth $(\% v / v)$ & $\operatorname{Pr}(g / L ~ h)$ & $Y_{\mathrm{P} / \mathrm{S}}(\mathrm{g} / \mathrm{g})$ \\
\hline All-malt wort process $\left(12^{\circ} \mathrm{P}\right)$ & 75.5 & 4.74 & 0.50 & 0.43 \\
\hline Wort with banana adjunct $\left(12^{\circ} \mathrm{P}\right)$ & 72.0 & 5.30 & 0.58 & 0.45 \\
\hline Wort with more banana adjunct $\left(15^{\circ} \mathrm{P}\right)$ & 84.0 & 6.39 & 0.60 & 0.42 \\
\hline
\end{tabular}

40 h, with high cell viability (100-98\%). However, the cell viability decreased to $95-90 \%$, probably due to the combination of lower substrate concentrations and higher ethanol concentrations after $40 \mathrm{~h}$. Of the several factors known to affect the yeast fermentative capacity, the composition of the medium is one of the most important [24].

Following this preliminary fermentation experiment, two trials were conducted in pilot scale at a constant temperature of $15{ }^{\circ} \mathrm{C}$ with concentrations of malt wort from $10{ }^{\circ} \mathrm{P}$ to 12 and $15^{\circ} \mathrm{P}$. The cell viability results (in relation to the total number of cells in suspension) using worts concentrated with banana juice are shown in Fig. 5. There was little variation of cell viability between 12 and $15^{\circ} \mathrm{P}$ concentrations. However, improvement in stability with higher banana juice concentrations (Fig. 4) indicated a positive effect of the nutrients or sugar profiles from banana on the viability and performance of brewer's yeast cells.

Figure 5 also shows that during the first hours of fermentation the number of yeast cells in suspension increased, then decreased due to flocculation. This profile is in agreement with that obtained with all-malt wort (Fig. 3). However, in contrast with the trial using allmalt wort, the fermentation with banana juice adjuncts under the same conditions of concentration $\left(12^{\circ} \mathrm{P}\right)$ showed a maximum number of yeast in suspension at an earlier stage of the fermentation and with a more defined profile (Fig. 5). Willaert [25] mentioned that the biomass peak, resulting from the flocculation of the yeast cells, can influence the total consumption of the fermentable sugars as maltose and that a higher attenuation with less raw material loss can be obtained by preventing the sedimentation of the yeast cells.

From the results shown in Fig. 6, it is important to note that the wort with higher initial extract concentration $\left(15^{\circ} \mathrm{P}\right)$ produced more ethanol than the one with traditional

Fig. 7 Specific substrate consumption rates $(1 / \mathrm{h})$ of the fermentable sugars during fermentation process of wort supplemented with banana juice $\left(15^{\circ} \mathrm{P} / 15^{\circ} \mathrm{C}\right)$ : maltose (empty square), glucose (empty triangle), fructose (empty circle), and maltotriose (empty diamond)

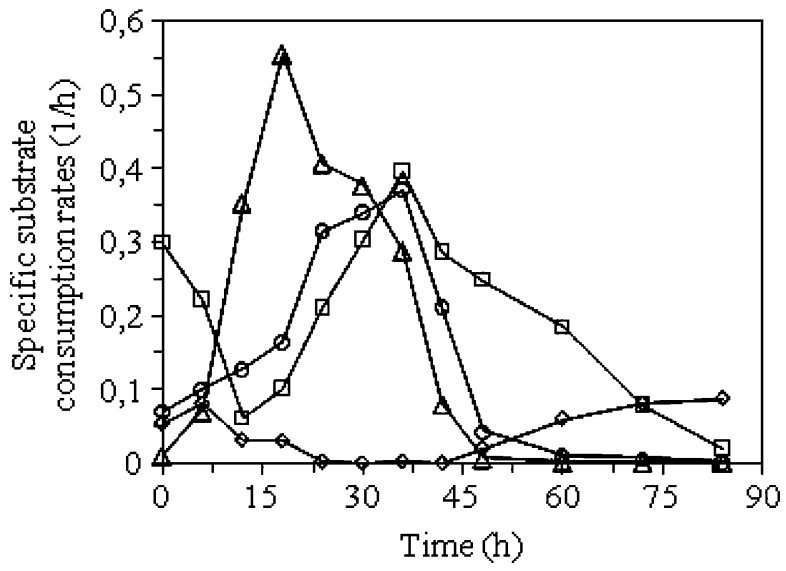


Fig. 8 Glucose and fructose concentrations during fermentation processes of wort supplemented with banana juice under the following conditions: $12{ }^{\circ} \mathrm{P} / 15^{\circ} \mathrm{C}$ (glucose - empty triangle and fructoseempty circle), and $15^{\circ} \mathrm{P} / 15^{\circ} \mathrm{C}$ (glucose-filled triangle and fructose-filled circle)

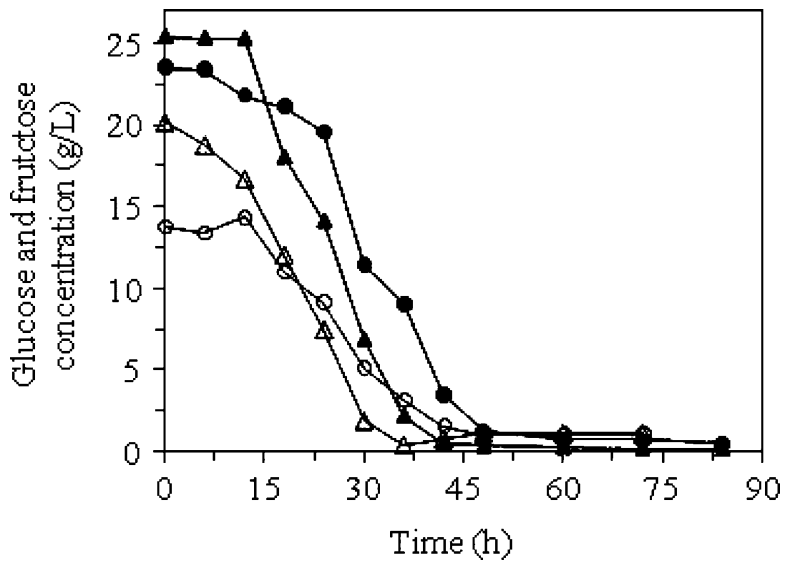

concentration $\left(12^{\circ} \mathrm{P}\right)$. Table 1 shows the main fermentation parameters obtained for beer production processes using all-malt wort and wort with banana juice as adjunct. In these cases, the higher value of fermentable carbohydrate concentration due to the banana juice adjunct may be the reason for the higher ethanol volumetric productivities. There is, however, evidence to show that when the banana juice is used as adjunct in the brewing wort, the efficiency of fermentation may be increased. The different nutrients found in the banana juice together with the fermentable sugars present in this type of extract may be the reason for this behavior of the system.

According to Navarro et al. [26], the sugars in wort are not all fermented equally well. Since the yeast has to hydrolyze sugar polymers before it can use them, it always attacks hexoses first. In our work, as shown in Fig. 7, comparing the specific rates of consumption for each fermentable sugar found in concentrated wort with banana juice as adjunct $\left(15^{\circ} \mathrm{P}\right)$, the following order of assimilation was observed: glucose was consumed first, followed by fructose, maltose, and finally maltotriose. The uptake and consumption of maltose and maltotriose was repressed or partially inactivated due to elevated glucose concentration. According to Willaert [25], only after $60 \%$ of the wort glucose has been used by the yeast, can maltose be consumed. Willaert [25] also showed that maltotriose uptake is inhibited by

Fig. 9 Maltose and maltotriose concentrations during fermentation processes of wort supplemented with banana juice under the following conditions: $12^{\circ} \mathrm{P} /$ $15{ }^{\circ} \mathrm{C}$ (maltose-empty square and maltotriose-empty diamond), and $15^{\circ} \mathrm{P} / 15^{\circ} \mathrm{C}$ (maltose-filled square and maltotriose-filled diamond)

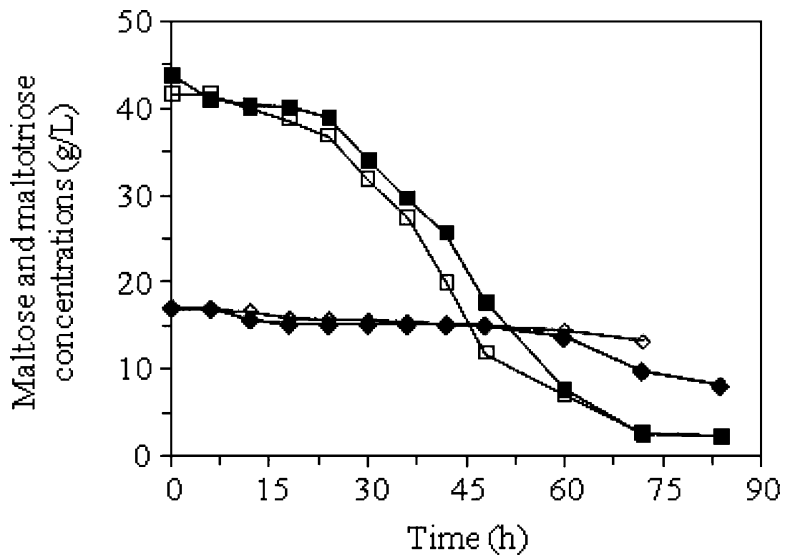


high glucose and maltose concentrations, which is in agreement with the behavior found in this research.

Figure 8 shows that the main consumption of glucose and fructose in the wort fermentation of 12 and $15{ }^{\circ} \mathrm{P}$ with banana juice as adjunct occurred approximately at 38 and $45 \mathrm{~h}$, respectively. The difference in the consumption profile of these sugars was probably due to the difference in the initial concentration, which in turn was due to the use of different concentrations of banana juice in the initial worts. However, as the preparation conditions and amounts of all-malt wort were kept constant, the consumption behavior of maltose and maltotriose was nearly almost independent of the wort concentrations used (Fig. 9). The difference is in agreement to the delay in the consumption of one of the sugars (the fructose) or of both (glucose and fructose) when using higher wort concentration $\left(15^{\circ} \mathrm{P}\right)$.

The color of the wort produced with banana juice as adjunct is slightly darker than the one obtained from all-malt worts or from traditional commercial processes. At present, it is still not clear whether there is a direct relationship between banana concentration as adjunct and color development during fermentation stage. However, it is very likely that enzymes present in the fruits (such as polyphenol oxydase) will contribute to the appearance of a darker color (enzymatic browning).

It is well known that the fermentation of worts of high specific gravity often leads to unbalanced flavor profiles [27]. Furthermore, in this type of process, the relative amounts of different assimilable sugars in wort also have an influence on trace compounds extremely important for the flavor profile in general. Worts containing higher glucose and fructose produce more esters than worts with high maltose contents [28-30]. The reason for the difference in ester production between glucose- or maltose-grown cells is still unclear. Thus, as the ester production is responsible for the fruity character of fermented beverages, volatile esters constitute an important group of aromatic compounds in beer. In modern high gravity fermentations, which are performed in tall cylindroconical vessels, the beer ester balance is often suboptimal, resulting in a clear decrease in beer quality [27]. Thus, when using banana as adjunct in the brewing process, some advantage in this sense is expected. The use of banana adjuncts may improve processes that improve beer quality.

\section{Conclusions}

For the fermentation conditions evaluated in this research, increases in the initial sugar concentration of brewing all-malt wort from $10{ }^{\circ} \mathrm{P}$ to 12 and $15{ }^{\circ} \mathrm{P}$ by using banana juice adjuncts increased in ethanol production, with volumetric productivity of approximately $0.6 \mathrm{~g} /(\mathrm{L} \mathrm{h})$ and an ethanol yield coefficient close to conventional conditions $\left(\approx 0.4 \mathrm{~g} / \mathrm{g}, Y_{\mathrm{P} / \mathrm{s}}\right)$. It can be concluded that banana juice used as adjunct in brewing methods aids in the development of new and different brewing products (by the use of simple techniques of preparation of banana juice). However, further work is needed to provide an understanding of the organoleptic profile obtained during the process of beer production using banana juice as adjunct.

Acknowledgments The authors acknowledge the financial support from Fapesp (Fundação de Amparo à Pesquisa do Estado de São Paulo/Brasil), CAPES (Coordenação para Aperfeiçoamento do Ensino Superior/ Brasil), GRICES (Gabinete de Relações Internacionais da Ciência e do Ensino Superior/Portugal), and FCT (Fundação para a Ciência e Tecnologia/Portugal), as well as the assistance from Malteria do Vale, Wallerstein Industrial \& Commercial, Johnson-Diversey, Novozymes, and EMATER-MG for supplying brewing materials and banana fruits. 


\section{References}

1. Linko, M., Haikara, A., Ritala, A., \& Penttilä, M. (1998). Journal of Biotechnology, 65, 85-98. doi:10.1016/S0168-1656(98)00135-7.

2. Bamforth, C. W. (2000). Journal of the Science of Food and Agriculture, 80, 1371-1378. doi:10.1002/ 1097-0010(200007)80:9<1371::AID-JSFA654>3.0.CO;2-K.

3. Willaert, R., \& Nedovic, V. A. (2006). Journal of Chemical Technology and Biotechnology (Oxford, Oxfordshire), 81, 1353-1367. doi:10.1002/jctb.1582.

4. Brányik, T., Silva, D. P., Vicente, A. A., Lehnert, R., Almeida e Silva, J. B., Dostálek, P., et al. (2006). Journal of Industrial Microbiology \& Biotechnology, 33, 1010-1018. doi:10.1007/s10295-006-0151-y.

5. Rivera, A., González, J. S., Carrillo, R., \& Martínez, J. M. (2009). Journal of Cleaner Production, 17(2), 137-142. doi:10.1016/j.jclepro.2008.03.009.

6. Almeida, R. B., Almeida e Silva, J. B., Lima, U. A., Silva, D. P., \& Assis, A. N. (2001). Brazilian Journal of Chemical Engineering, 18(4), 459-465. doi:10.1590/S0104-66322001000400010.

7. Almeida e Silva, J. B., Lima, U. A., Silva, D. P., Almeida, R. B., \& Assis, A. N. (2004). Cerevisia, 29(3), 147-154.

8. Dragone, G., Silva, D. P., \& Almeida e Silva, J. B. (2004). Lebensmittel-Wissenschaft und-Technologie, 37, 797-802.

9. Silva, D. P., Brányik, T., Dragone, G., Vicente, A. A., Teixeira, J. A., \& Almeida e Silva, J. B. (2008). Chemical Papers, 62(1), 34-41. doi:10.2478/s11696-007-0076-6.

10. Casey, G., Magnus, C. A., \& Ingledew, W. M. (1984). Applied and Environmental Microbiology, 48, 639-646.

11. McCaig, R., McKee, J., Pfisterer, E. A., Hysert, D. W., Munoz, E., \& Ingledew, W. M. (1992). Journal of the American Society of Brewing Chemists, 50, 18-26.

12. Russel, I., \& Stewart, G. G. (1995). Brewing. In: H. J. Rehm, G. Reed (eds.), Biotechnology. New York: VCH, v.9, cap. 11.

13. Stewart, G. G., Bothwick, R., Bryce, J., Cooper, D., Cunningham, S., Hart, C., et al. (1997). MBAA Technical Quarterly, 34, 264-270.

14. van Iersel, M. F. M., van Dieren, B., Rombouts, F. M., \& Abee, T. (1999). Enzyme and Microbial Technology, 24, 407-411.

15. Odibo, F. J. C., Nwankwo, L. N., \& Agu, R. C. (2002). Process Biochemistry, 37, 851-855. doi:10.1016/ S0032-9592(01)00286-2.

16. Agu, R. C. (2006). Technical Quarterly-Master Brewers Association of the Americas, 43, $277-280$.

17. Harish, S., Kavino, M., Kumar, N., Saravanakumar, D., Soorianathasundaram, K., \& Samiyappan, R. (2008). Applied Soil Ecology, 39, 187-200. doi:10.1016/j.apsoil.2007.12.006.

18. Zhang, P., Whistler, R. L., BeMiller, J. N., \& Hamaker, B. R. (2005). Carbohydrate Polymers, 59, 443458. doi:10.1016/j.carbpol.2004.10.014.

19. FAO, Food and Agriculture Organization of the United Nations.(2008) FAOSTAT statistics database http://faostat.fao.org/site/567/DesktopDefault.aspx?PageID=567 (last updated 11 May 2008).

20. Viviani, L., \& Leal, P. M. (2007). Revista Brasileira de Fruticultura, 29(3), 465-470. doi:10.1590/ S0100-29452007000300012.

21. Loeseck, H. W. (1950). Chemical changes during ripening. Bananas-chemistry, physiology and technology (vol. 4). New York: Interscience.

22. ASBC, American Society of Brewing Chemists (1996). Methods of Analysis of American Society of Brewing Chemists. ASBC. 8th ed. Saint Paul Minnesota. USA.

23. Le Duy, A., \& Zajic, E. J. (1973). Biotechnology and Bioengineering, 15, 805-810. doi:10.1002/ bit.260150412.

24. Guido, L. F., Rodrigues, P. G., Rodrigues, J. A., Goncalves, C. R., \& Barros, A. A. (2004). Food Chemistry, 87, 187-193. doi:10.1016/j.foodchem.2003.10.033.

25. Willaert, R. (1991). Cerevisia, 26, 43-49.

26. Navarro, S., Pérez, G., Navarro, G., Mena, L., \& Vela, N. (2007). Food Chemistry, 105, $1495-1503$. doi:10.1016/j.foodchem.2007.05.035.

27. Verstrepen, K. J., Derdelinckx, G., Dufour, J. P., Winderickx, J., Thevelein, J. M., Pretorius, I. S., et al. (2003). Journal of Bioscience and Bioengineering, 96(2), 110-118.

28. Engan, S. (1972). Wort composition and beer flavour. II: The influence of different carbohydrates on the formation of some flavour components during fermentation. Journal of The Institute of Brewing. Institute of Brewing (Great Britain), 78, 169-173.

29. Younis, 0. S., \& Stewart, G. G. (1998). Journal of the Institute of Brewing, 104, 255-264.

30. Younis, 0. S., \& Stewart, G. G. (1999). Journal of the American Society of Brewing Chemists, 57, 39-45. 